"Corporate Social Responsibility or Corporate Social Irresponsibility: where should be the focus?"

\begin{tabular}{|c|c|}
\hline AUTHORS & Sulphey M. M. (D https://orcid.org/0000-0001-6042-2123 \\
\hline ARTICLE INFO & $\begin{array}{l}\text { Sulphey M. M. (2017). Corporate Social Responsibility or Corporate Social } \\
\text { Irresponsibility: where should be the focus?. Problems and Perspectives in } \\
\text { Management, 15(4), 293-301. doi:10.21511/ppm.15(4-1).2017.13 }\end{array}$ \\
\hline DOI & http://dx.doi.org/10.21511/ppm.15(4-1).2017.13 \\
\hline RELEASED ON & Monday, 25 December 2017 \\
\hline RECEIVED ON & Sunday, 10 September 2017 \\
\hline \multirow[t]{2}{*}{ ACCEPTED ON } & Thursday, 05 October 2017 \\
\hline & $(\mathrm{oc}) \mathrm{EY}$ \\
\hline LICENSE & $\begin{array}{l}\text { This work is licensed under a Creative Commons Attribution } 4.0 \text { International } \\
\text { License }\end{array}$ \\
\hline JOURNAL & "Problems and Perspectives in Management" \\
\hline ISSN PRINT & $1727-7051$ \\
\hline ISSN ONLINE & $1810-5467$ \\
\hline PUBLISHER & LLC "Consulting Publishing Company "Business Perspectives" \\
\hline FOUNDER & LLC "Consulting Publishing Company "Business Perspectives" \\
\hline & $\begin{array}{l}=-: \\
= \pm=-\end{array}$ \\
\hline NUMBER OF REFERENCES & NUMBER OF FIGURES \\
\hline 58 & 0 \\
\hline
\end{tabular}

(C) The author(s) 2022. This publication is an open access article. 


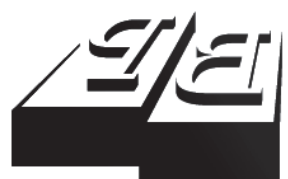

BUSINESS PERSPECTIVES

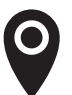

LLC "CPC "Business Perspectives" Hryhorii Skovoroda lane, 10, Sumy, 40022, Ukraine

www.businessperspectives.org

Received on: $10^{\text {th }}$ of September, 2017 Accepted on: $5^{\text {th }}$ of October, 2017

(C) M. M. Sulphey, 2017

M. M. Sulphey, Ph.D., Professor, College of Business Administration, Prince Sattam Bin Abdulaziz University, Saudi Arabia.

\title{
CORPORATE SOCIAL RESPONSIBILITY OR CORPORATE SOCIAL IRRESPONSIBILITY: WHERE SHOULD BE THE FOCUS?
}

\begin{abstract}
With multiple scandals and a host of disingenuous actions creating ripples across the corporate world, it is high time that Corporate Social Irresponsibility (CSI) is accorded the due importance, at par with Corporate Social Responsibility (CSR), by academia and the industry. CSI refers to situations wherein firms fail to meet a "minimum behavioral standard with respect to the corporation's relationship with its stakeholders". There have been many instances wherein CSI and corporate wrongdoings have been covered up with CSR. Many scholars consider CSR and CSI as opposite forces that are interconnected and interdependent, and take turns in giving rise to each other. CSI, being an emergent and a topical subject area, is yet to develop in terms of theory, and is still evolving. The present work attempts to motivate further investigation in the emerging area by presenting theoretical views and available accumulated empirical works. The study has puts across a fair view of the topic. It is expected that the present work will stimulate scholars to take up further investigation in the emerging area.
\end{abstract}

\section{Keywords}

\section{JEL Classification}

Corporate Social Responsibility, corporate Social Irresponsibility, corporate wrongdoing, Capitalist Social Responsibility, ethics

\section{INTRODUCTION}

Since the 1950s, the concept of Corporate Social Responsibility (CSR) has been discussed and debated intensively by professionals of the industry, government and non-governmental organizations, and researched extensively in the academic circles (Tench, Sun, \& Jones, 2015). At any point of time, a plethora of governmental and non-governmental organizations are involved in a host of CSR initiatives involving billions of dollars around the globe. The concept, however, does not constrain itself to a single definition and has been defined in numerous ways (Carroll, 1979, 1991). It is seen as "a construct that is individual to the stakeholder that defines it" (Jones, Bowd, \& Tench, 2009), a social contract that the organizations have with their respective stakeholders (Bowd, Jones, \& Tench, 2005), and often means different things to different people. It is also opined by Jones et al (2009) that "it is unlikely that one unifying definition will be agreed upon given the competing agendas of different stakeholders". Of late CSR has succeeded in gaining a higher profile on the political, economic and business agendas across economies (Arpan, 2005; Birch, 2008; Riese, 2007), and has received a large than life image. But does this deliver a balanced outlook? 
A cursory look in the industrial scenario reveals that in the past few decades, the corporate world have been replete with multiple scandals, crisis, and a host of disingenuous actions that have send ripples across the globe. In the previous century, the Union Carbide, Enron, and Worldcom episodes were a few instances that epitomize irresponsibility in the corporate sector. The recent decades also have its share of corporate scandals. The collapse of Lehman Brothers, BP oil spill at Gulf of Mexico, the phone hacking at News International, the mis-selling of Glaxo Smith Kline in the US, the anti-pollution fiasco of Volkswagen, and the inter-banking rate fixing of Barclays are just a few of them. The financial and economic crisis that shook the world recently and questioned the credibility of many large corporate houses have been well documented and analyzed threadbare by many experts in the field (Bishop \& Green, 2010; Levine, Locke, Searls, \& Weinberger, 2000; Roubini \& Mihm, 2010; Tett, 2010). While in the News International scandal several journalists and politicians have been arrested, in the case of Glaxo Smith Kline (GSK) and Barclays, fines to the tune of $\$ 3$ billion and $£ 290$ million, respectively, have been imposed. Claims to the tune of billions of dollars have been filed against Volkswagen in various parts of the globe.

The irony in many instances is that CSR is often used to divert attention from wrongdoings. For instance, at the very same time when GSK was found to be indulging in mis-selling of drugs, the company's annual CSR report (running over 100 pages) detailed its benign pledges to "improve access to healthcare in the developing world and cut its carbon footprint" (Macalister, 2012). The public came to know about the damning issues of the company only when it was discovered and reported. These disingenuous actions and economic crimes, which led to toxic debts and collapses, occurred despite a host of initiatives and regulations imposed by various governments and central banks. It is also commented that CSR provides managers with a host of discretionary powers putting the interests of shareholders' and stakeholders' at jeopardy (Karnani, 2010). It could considerably delay or even go to the extent of discouraging effective solutions to many corporate problems.

An analysis of most of the corporate crimes reveal that there exists a common thread that points to the fact that these crimes have been committed not just by a single organization, but across the industry (Bishop \& Green, 2010; Tench et al., 2015; Tett, 2010). These events and its aftermath, which have been watersheds in corporate history, have prompted many experts and professionals to doubt the utility of CSR. There are many who opine that CSR has failed in favor of Corporate Social Irresponsibility (CSI) (Bowd et al., 2005; Jones et al., 2009; Stokes, 2015; Tench et al., 2015). To them CSR and CSI form part of an opposing continuum. Adequate literature exist that point towards instances wherein CSR has disastrously failed, and have not contributed as they ought to have (Macalister, 2012; Tench et al., 2015; Treanor, 2012). The destruction and its scale, according to Jones (2015), direct one to think about CSI and not CSR. According to Corporate Watch (2006), though CSR has been used as public campaigns to "do good", it is often used to "divert attention from the damaging impact of corporate social irresponsibility and deflect concern about the underlying problem of corporate power". Further, the caustic comment of George Osborne, the UK Chancellor of the Exchequer that we are now dwelling in the "age of irresponsibility" is worth noting.

Despite all these, the topic of CSI has received scant scholarly attention (Tench et al. 2015), and is still a less explored area (Lioui \& Sharma, 2012; Muller \& Kräussl, 2011; Oikonomou, Brooks, \& Pavelin, 2012; Tench et al., 2012). This is because CSI is a new area of study (Bansal \& Kandola, 2003; Kotchen \& Moon, 2007) and is still an emergent and nascent topic (Jones, 2015). Scholarly attention in CSI has started picking only recently (Lange \& Washburn, 2012; Murphy \& Schlegelmilch, 2013; Popa \& Salanță, 2014); mostly in the wake of a host of $21^{\text {st }}$ century corporate failings (Kotchen \& Moon, 2007; Wagner, Bicen, \& Hall, 2008). It has still to develop itself in terms of theory (Jones et al., 2009).

The concept can also be considered to be vague as Economists and theoreticians have been using the word "irresponsibility without giving full and due regard to its meaning or how it might be addressed at policy level" (Jones, 2015). Based on this trend, this study presents theoretical views and available accumulated empirical efforts to put across a fair view of CSI so that further investigation in the emerging area is inspired. 


\section{REVIEW OF LITERATURE}

\subsection{What is CSI?}

A clear and definite definition for CSI is yet to emerge. Strike, Gao, and Bansal (2006) defined CSI as "the set of corporate actions that negatively affects an identifiable social stakeholder's legitimate claims (in the long run)". This definition focuses on the long run negative effects that may accrue to the various stakeholders due to corporate actions. According to Campbell (2007), CSI refers to such situations wherein firms fail to meet a "minimum behavioral standard with respect to the corporation's relationship with its stakeholders". Pearce and Manz (2011) defined it as:

"unethical executive behavior that shows disregard for the welfare of others, that at its extreme is manifested when executives seek personal gain at the expense of employees, shareholders and other organization stakeholders, and even society at large"

This definition seems to have limited CSI to executive behavior and the focus is merely on them and their unethical behavior of seeking personal gratification. In a more recent definition, Tench et al. (2015) focus on the (il)legality and define CSI as "those business behaviours and actions that are illegal; or legal but severely unsustainable and/or unethical and thus totally socially unacceptable". To Campbell (2007), CSI relates to situations in which the firm does not meet a "minimum behavioral standard with respect to the corporation's relationship with its stakeholders". Based on the works of Campbell (2007), Vogel (1992), Murphy and Schlegelmilch (2013), Mazzei, Gangloff and Shook (2015), we identified aspects like "deceiving customers, exploiting employees or suppliers, putting consumers at risk, poisoning the environment, and cheating the government" to constitute CSI. Linking CSI to CSR Herzig and Moon (2013) states that CSR refers to "the business responses to the expectations of society", and CSI is "the failure of businesses to meet these expectations". Elaborating on the use of the word "irresponsibility", and addressing the vagueness of the concept, Jones (2015) comments that:

"from societal, political, economic, business practice and practitioner viewpoints, the issue is very topical in that during the 2007-2010 financial crises, politicians, economists and commentators used the word irresponsibility without giving full and due regard to its meaning or how it might be addressed at policy level."

Lange and Washburn (2012) related CSI to concepts like corporate culpability and undesirability. A comprehensive definition that takes into consideration the complexity of the issue is thus yet to evolve.

\subsection{Theoretical underpinning}

As stated elsewhere, CSI is yet to develop in terms of theory (Jones et al., 2009). It is an "emergent (nascent) and topical subject area” (Jones, 2015), and is still evolving. It is considered as emergent since it is a new area of academic study (Bansal \& Kandola, 2003; Kotchen \& Moon, 2007). It is considered topical since during the financial crises of the past decade the word 'irresponsibility' has been used by economists, politicians, academicians and scholars "without giving full and due regard to its meaning or how it might be addressed at policy level" (Jones, 2015). The crisis originated in US as a result of irresponsible lending in the subprime mortgage market. The intensity and magnitude of the crises, which was unprecedented and more or less similar to that of the 1930s, generated all-round discussions and condemnation about the irresponsibility of bankers. Later a number of corporate failings, which included Enron and Worldcom, moulded the concept of CSI into a new academic area (Kotchen \& Moon, 2007; Wagner et al., 2008). The concept is now evolving in term of theory and research.

\subsection{Relationship with CSR}

There are conflicting view points with respect to the relationship of CSI, vis-a-vis CSR. Stokes (2015) state that multiple and recurrent bouts of scandals and disingenuous actions in corporate world has resulted in failure of CSR, and alternatively this has resulted in the emergence of CSI. Tench et al. (2015) are of the opinion that both CSR and CSI coexist, and can be transformable to each other. According to them if CSI is eliminated or reduced, it will lead to significant increase in CSR. Windsor (2013) is of the opinion that con- 
trolling CSI is far more important than the promotion of CSR. Another distinguishing factor between CSR and CSI is their definability. It is possible to relatively easily and clearly define CSI in a societal context. Bowd et al. (2005), Jones et al. (2009), Stokes (2015), Tench et al. (2015) present the case of CSR and CSI as part of an opposing extreme continuum. According to Tench et al. (2015), while CSI is having a finite endpoint, CSR is infinitely scalable.

Opposing views about CSI are also in vogue. There are many experts who consider CSI as a concept distinct from CSR (Chatterji, Levine, \& Toffel, 2009; Godfrey, Merrill, \& Hansen, 2009; Kotchen \& Moon, 2012; Lange \& Washburn, 2012; Muller \& Kräussl, 2011). More recently, Walker, Zhang, and Yu (2016) also opined that CSR and CSI are two separate and non-symmetrical concepts. These propositions however seem to be drowned in the so called "integrative" appeal.

Tench et al. (2015) attempted to reframe CSR by considering CSI as an integrative component. They opined that within a conceptual framework, CSR will cease to exist without the concept of CSI. The two concepts can be considered to be dichotomous, and work as opposite forces "in a systemic whole". Both these opposite forces are interconnected and interdependent, and take turns in giving rise to each other. Going one step forward they argued that there is incomplete conceptualization of CSR, since CSI was neglected and adequate research about it is lacking. According to them, CSR is indefinable and confusing without the equally important and "opposite concept as a frame of reference". Further, CSR can be clearly defined only by considering what CSR is not. Thus they brought out the importance of CSI by stating that it is essential in the understanding and generating of CSR.
Armstrong, as early as in 1977 , conceptualized that CSI can occur in two occasions - one when great harm has been caused to the system, and the next is when it can be generally agreed that an irresponsible act has occurred. In a similar line, Tench et al. (2015) theorize that CSI has two categories of business behaviors - one which is totally illegal, socially irresponsible, and the other that is legal, but socially irresponsible. Thus they emphasises that "certain legal behaviours can be defined as CSI in a society - this is why the concept of CSI is powerful and useful". They further elaborate that the definition of CSI should be subject to various aspects like "societal norms, traditions, cultures, expectations, conditions and contingent factors".

Nunn (2015) takes a pessimistic view of CSR and re-articulates it as "Capitalist Social Responsibility", as according to him CSR reflect only the interests of the capitalist class. The fact is that at times CSR camouflages itself to look like it aligns with the interests of other social groups. It often works to masks and entrenches competitive strategies and/or exploitative social relations. He considers this idea to be a productive analytical tool to understand what is really at work when considering either corporate "responsibility" or "irresponsibility". CSI could be part of a broad political project that could be put to use to "identify and expose exploitation in an effort to transform social relations".

The entire body of the theory about CSI thus presents a vivid picture of an important aspect that was not accorded its due importance (Lioui \& Sharma, 2012; Oikonomou et al., 2012; Tench et al., 2012). Further, theorists are more or less unanimous in proposing that CSR can be defined and understood in its entirety only through and by its other half - CSI (Bowd et al., 2005; Jones et al., 2009; Stokes, 2015; Tench et al., 2015). For a better

Table 1. Differing views about CSI

\begin{tabular}{|c|c|c|}
\hline No & Approach & Authors \\
\hline 1 & Integrative & $\begin{array}{l}\text { Bowd et al.(2005), Jones et al. (2009), Stokes (2015) - CSR and CSI as part of an opposing extreme } \\
\text { continuum. } \\
\text { Stokes (2015) - CSR and CSI point towards opposite directions. } \\
\text { Tench et al. (2015) - both CSR and CSI coexist and can be transformable to each other. }\end{array}$ \\
\hline 2 & Separate & $\begin{array}{l}\text { Walker, Zhang, and Yu (2016) - CSR and CSI are two separate and non-symmetrical concepts. } \\
\text { Chatterji et al. (2009), Godfrey et al. (2009), Kotchen and Moon (2012), Muller and Kraussl (2011) - CSR } \\
\text { and CSI are conceptually distinct construct. }\end{array}$ \\
\hline
\end{tabular}


understanding, the different views about CSI are presented in Table 1.

Based on the review of the available literature, the present work also subscribes to the view that CSR and CSI coexist, are interconnected and interdependent, points to the opposite direction, and take turns in contributing to each other.

\subsection{Why do firms involve in CSI?}

A few social scientists have attempted to identify the factors that lead to CSI (Anand et al., 2004; Ashforth \& Anand, 2003; Trevino \& Brown, 2004). They have focused on a host of diverse perspectives which included philosophy, psychology, business, etc. For instance, while philosophy looked at the role of standards and moral behavior, business science focused on the agent's perspective and psychology was more into individual differences (Singer, 2000).

Baucus (1994) identified industry pressure as one of the important predictors of CSI. Industrial scenario offer pressure, as well as opportunity to either involve in or refrain from socially irresponsible activities. Erickson, Crosnoe, and Dornbusch (2000) are of the opinion that decisions to act in an irresponsible manner are often not made in isolation. Such decisions are normally taken under the influence of the so called "socially constructed standards". When there is a general degradation in societal standards, organizations feel the pressure and deviate from the set norms so as to stay competitive. Straying away from the set norms and the consequent misconduct and irresponsibility are also aided by loose regulatory policies and bodies. When regulatory policies/bodies are lax, firms tend to involve in irresponsible activities without any fear or risk of punishment (Baucus, 1994). When regulatory policies are strict, firms stay away from irresponsible activities.

Strain theory, derived from rational choice theory, can be extended to explain the occurrence of CSI. According to the strain theory, firms that have either higher levels of performance aspirations or investor/public expectations would tend to push boundaries or change goalposts towards a sort of acceptable corporate action, so as to achieve the desired level of aspirations/expecta- tions (Mishina, Dykes, Block, \& Pollock, 2010). Thus the extreme desire by firms to have/maintain a respectable position in the market would result in CSI. This was evident in the case the Indian multinational Information Technology giant "Satyam Computers Ltd", which cooked up figures for over a period of time in order to meet market expectations.

There are also certain firms that target extraordinary performance and unrealistic goals. Members of such firms are compelled to attempt alternative goals to achieve such goals. Such alternative goals may fuel socially irresponsible behavior (Greve, Palmer, \& Pozner, 2010).

Organizational leadership also tend to influence/ abet irresponsible behavior. Leaders provide cues as to how to interpret and respond to various problems faced by the organizations (Thomas, Clark, \& Gioia, 1993). Any favorable disposition of the leaders towards CSI will make the organizational members to cite them as role models and consider such behaviors to be acceptable (Weaver, Treviño, \& Agle, 2005). As time progresses such irresponsible behaviors could solidify into norms, which will subsequently be shared among other organization members (Kostova, 1997). Even though the top management may not involve in CSI, they could be fostering such behavior when they knowingly or unknowingly reward, condone, ignore, or covering up irresponsible behaviors committed by members (Zahra, Priem, \& Rasheed, 2005). Mazzei et al. (2015) are of the opinion that individual effects act in a significant manner to account for variances in CSI.

From the above discussions, it can be assumed that firms involve in CSI due to a multitude of factors ranging from degradation of societal standards, industry pressure, lax regulatory policies/ bodies, to unrealistic performance expectations, the desire to maintain a respectable market position and leadership.

\subsection{Studies in CSI}

Though interest in CSI span for over three decades, empirical examination of the concept is still limited (Lange \& Washburn, 2012). A few studies have brought out the damaging effect of CSI (Lioui \& 
Sharma, 2012; Oikonomou et al., 2012; Walker et al., 2016). The present section presents a few studies in the area of CSI. According to Tench et al. (2015), "getting it wrong in relation to CSR, in other words operating in a CSI manner, can have disastrous social, economic and business consequences". Kotchen and Moon (2011) analyzed the data of over 3000 listed companies of US over a period of 15 years and found that companies engaged in CSR mostly to offset their CSI. A classical example is that of Barclays. Barclays was considered as a peerless good corporate citizen, and they had spent millions of pounds for sponsoring football's Premier League. According to Treanor (2012), this was done to bolster their PR credentials'. In the background Barclays was indulging in inter-banking rate fixing. It is also reported that, in addition to Barclays, many other banks including international ones were also involved in manipulating inter-bank rates, for the period from 2005 to 2008.

The available literature exhibits a clear research bias in favor of CSR over CSI (Walker, Zhang, \& Yu, 2016). The potential benefits as a result of CSR seemed to have been researched extensively at the cost of CSI. Herzig and Moon (2013) studied the financial sector at the height of financial crisis and recession for the period from 2007 to 2010 . They concluded that CSR can precede CSI, as well as CSI can exist in the absence of CSR, or they could even exist simultaneously. As opposed to this, Walker, Zhang and Yu (2016) did a study to empirically demonstrate that CSR and CSI are two separate and non-symmetrical concepts.

Walker et al. (2016) using over 10,000 observations for a period of five years, from 2009 to 2013, examined how increase in CSR and CSI is connected to firm performance. It was also examined how increases in CSR in the presence of CSI relate to firm performance: profitability, management efficiency and market valuation. Results show that increased CSR was related significantly to increased firm performance and, alternatively, increased CSI was found to be significantly related to decreased profitability. Another noteworthy finding was that when there is simultaneous presence of CSR and CSI, the former was found to have a dominant positive effect. Margolis and Walsh (2003) found a positive relationship between CSR and firm performance. A meta-analytic study by Orlitzky, Schmidt, and Rynes
(2003) found a positive relationship between CSR and firm performance. It can thus be inferred that CSR and firm performance are positively related.

A number of studies found negative relationships between CSI and firm performance (Baron, Harjoto, \& Hoje, 2011; Lioui \& Sharma, 2012; Muller \& Kräussl, 2011; Oikonomou et al., 2012). It has also been found by Walker et al. (2016) that increases in CSI could significantly reduce return on assets (ROA). According to them, though higher levels of CSI will affect profitability, it was not found to be significantly related to management efficiency or market value. A host of costs ranging from damaged stakeholder relationships, tainted corporate reputations (Muller \& Kräussl, 2011), increased financial risk (Lioui \& Sharma, 2012), and negative stock returns (Baron et al., 2011) could occur as a result of CSI. Thus it can be suggested that higher CSI is negatively related to firm performance. There are a few studies that have examined the effect of simultaneous existence of CSR and CSI on firm performance (Walker et al., 2016). Walker and Wan (2012) found that while firms often advertise and promote their CSR, and engage in increasing stakeholder awareness, they attempt to hide or downplay their CSI.

Mazzei et al. (2015) used a sample of 899 firms spread over 66 industries to empirically examine the effect of three levels (industry, firm, and individual) on CSR and CSI. They found that all the three examined levels influenced CSR and CSI. The study also estimated the magnitude of effects that can be attributed to each level for CSR and CSI. Focusing on the leadership aspect, Pearce and Manz (2011) examined the role of the type of power motivation of the organizational leader in determining CSI tendencies. The study proposed that a combination of the degree of centrality of leadership, and their primary power motivation significantly affected CSI. Wagner et al. (2008) analyzed the demographic angle of CSI and found that females and those with higher age are more sensitive toward irresponsible behavior of firms.

A few studies have empirically examined the effect of CSI. Studies have found that CSI result in anger (Romani, Grappi, \& Bagozzi, 2013) and moral outrage of stakeholders (Antonetti \& Maklan, 2016; Lindenmeier, Schleer, \& Pricl, 2012). Such moral outrage is found to further generate negative atti- 
tudes toward the firm (Grappi, Romani, \& Bagozzi, 2013), create a negative word-of-mouth (Grappi et al., 2013; Lindenmeier et al., 2012) and could even lead to consumer boycotts (Braunsberger \& Buckler, 2011; Cronin, Reysen, \& Branscombe, 2012). Some studies have also examined the simultaneous occurrence of CSR and CSI (Strike et al., 2006; Tang, Qian, Chen, \& Shen, 2015).
From the review, it can be found that empirical examinations with respect to CSI are only in its nascent stage. A few scattered scholarly examinations are available about CSI. A thorough and concerted effort in this direction is a definite must. The area offers ample scope to examine various factors and facets that aid/contribute or hold back CSI, as well as its effects.

\section{CONCLUSION}

In the current business scenario, where there are serious crises related to trust, finance and ecology, CSI is a definite area that needs to be provided its due attention. Though a negative connation, CSI need be accorded an appropriate position and be considered and an independent area of inquiry. The veracity of the crises that are revealed around the globe from time to time presents a case for the issue to be focused by scholars, managements, society and governments alike. The study attempted to present theoretical views and available empirical efforts about CSI so as to present a fair view of it, so as to motivate further investigation in the emerging area. CSI as a phenomenon that directly affects business and society deserves a better treatment and has to be more systematically studied and analyzed. It is earnestly hoped that the present piece of literature stimulates further examination of this emerging concept.

\section{REFERENCES}

1. Anand, V., Ashforth, B. E., \& Joshi, M. (2004). Business as Usual: The Acceptance and Perpetuation of Corruption in Organizations. Academy of Management Executive, 18, 39-53.

2. Antonetti, P., \& Maklan, S. (2016). An Extended Model of Moral Outrage at Corporate Social Irresponsibility. Journal of Business Ethics, 135, 429-444. https://doi.org/10.1007/s10551014-2487-y

3. Arpan, L. M. (2005). Integration of information about corporate social performance. Corporate Communications: An International Journal, 10(1), 83-98.

4. Ashforth, B. E., \& Anand, V. (2003). The Normalization of Corruption in Organizations. In R. M. Kramer and B. M. Staw (Eds.). Research in Organizational Behavior, 25 (pp. 1-52). (Elsevier, Amsterdam).

5. Bansal., P., \& Kandola, S. (2003). Corporate social irresponsibility: Why good people behave badly in organizations. Ivey Business Journal, (March/April), 1-5.
6. Baron, D. P., Harjoto, M. A., \& Hoje, J. (2011). The economics and politics of corporate social performance. Business and Politics, 13(2), 1-46.

7. Baucus, M. S. (1994). Pressure, opportunity, and predisposition: A multivariate model of corporate illegality. Journal of Management, 20(4), 699-721.

8. Birch, D. (2008). Analysis of CSR: principles and concepts. Social Responsibility Journal, 4(1/2), 129-135.

9. Bishop, M., \& Green, M. (2010). The road from ruin: How to revive capitalism and put America back on top. New York: Crown Business.

10. Bowd, R., Jones, B., \& Tench, R. (2005). CSR and the Media, Summary Research Report, Leeds Metropolitan University and Connectpoint, Leeds.

11. Campbell, J. L. (2007). Why would corporations behave in socially responsible ways? An institutional theory of corporate social responsibility. Academy of Management Review, 32(3), 946-967.
12. Carroll, A. (1979). A threedimensional conceptual model of corporate performance. Academy of Management Review, 4(4), 497-505.

13. Carroll, A. (1991). The pyramid of corporate social responsibility: toward the moral management of organizational stakeholders. Business Horizons, July-August.

14. Chatterji, A. K., Levine, D. I., \& Toffel, M. W. (2009). How well do social ratings actually measure corporate social responsibility? Journal of Economics \& Management Strategy, 18(1), 125-169.

15. Corporate Watch. (2006). What is wrong with corporate social responsibility. (Corporate Watch CSR Report 2006). Retrieved from http://www.corporatewatch. org/download.php?id=55

16. Cronin, T., Reysen, S., \& Branscombe, N. R. (2012). Wal Mart's conscientious objectors: Perceived illegitimacy, moral anger, and retaliatory consumer behavior. Basic and Applied Social Psychology, 34(4), 322-335. 
17. Erickson, K. G., Crosnoe, R., \& Dornbusch, S. M. (2000). A social process model of adolescent deviance: Combining social control and differential association perspectives. Journal of Youth and Adolescence, 29(4), 395-425.

18. Godfrey, P. C., Merrill, C. B., \& Hansen, J. M. (2009). The relationship between corporate social responsibility and shareholder value: an empirical test of the risk management hypothesis. Strategic Management Journal, 30(4), 425-445.

19. Grappi, S., Romani, S., \& Bagozzi, R. P. (2013). The effects of company offshoring strategies on consumer responses. Journal of the Academy of Marketing Science, 41(6), 683-704.

20. Greve, H., Palmer, D., \& Pozner, J. (2010). Organizations gone wild: The causes, processes, and consequences of organizational misconduct. Academy of Management Annals, 4(1), 53-107.

21. Herzig, C., \& Moon, J. (2013). Discourses on corporate social ir/responsibility in the financial sector. Journal of Business Research, 66(10), 1870-1880.

22. Jones, B., Bowd, R., \& Tench, R. (2009). Corporate irresponsibility and corporate social responsibility: competing realities. Social Responsibility Journal, 5(3), 300-310. http://dx.doi. org/10.1108/17471110910977249

23. Jones, B. (2015). Corporate social irresponsibility: The role of government and ideology. In Reframing Corporate Social Responsibility: Lessons from the Global Financial Crisis. 10 Mar 2015, 57-75. http:// dx.doi.org/10.1108/S20439059(2010)0000001009

24. Kostova, T. (1997). Country institutional profile: Concept and measurement. Academy of Management Best Paper Proceedings, 180-189. Boston, MA.

25. Kotchen, M. J., \& Moon, J. J. (2007). Corporate social responsibility for irresponsibility. U.C. Santa Barbara and NBER University of Pennsylvania.
Retrieved from http://www2.bren. ucsb.edu/Bkotchen/links/CSR904-07.pdf

26. Lange, D., \& Washburn, N. T. (2012). Understanding attributions of corporate social irresponsibility. Academy of Management Review, 37(2), 300-326.

27. Levine, R., Locke, C., Searls, D., \& Weinberger, D. (2000). The Cluetrain Manifesto: The end of business as usual. Cambridge, MA: Perseus Books.

28. Lindenmeier, J., Schleer, C., \& Pricl, D. (2012). Consumer outrage: Emotional reactions to unethical corporate behavior. Journal of Business Research, 65(9), 1364-1373.

29. Lioui, A., \& Sharma, Z. (2012). Environmental corporate social responsibility and financial performance: disentangling direct and indirect effects. Ecological Economics, 78, 100-111.

30. Macalister, T. (2012). Pharma overtakes arms industry to top the league of misbehaviour. The Observer, 8 July.

31. Margolis, J. D., \& Walsh, J. P. (2003). Misery loves companies: rethinking social initiatives by business. Administrative Science Quarterly, 48(2), 268-305.

32. Mazzei, M. J., Gangloff, A. K., \& Shook, C. L (2015). Examining multi-level effects on corporate social responsibility and irresponsibility. Management \& Marketing, 10(3), 163-184.

33. Mishina, Y., Dykes, B. J., Block, E. S., \& Pollock, T. G. (2010). Why "good" firms do bad things: The effects of high aspirations, high expectations, and prominence on the incidence of corporate illegality. Academy of Management Journal, 53(4), 701-722.

34. Muller, A., \& Kräussl, R. (2011). Doing good deeds in times of need: a strategic perspective on corporate disaster donations. Strategic Management Journal, 32, 911-929.

35. Murphy, P. E., \& Schlegelmilch, B. B. (2013). Corporate social responsibility and corporate social irresponsibility: Introduction to a special topic section. Journal of Business Research, 66(10), 18071813.

36. Nunn, A. (2015). The Structural Contradictions and Constraints on Corporate Social Responsibility: Challenges for Corporate Social Irresponsibility. In Corporate Social Irresponsibility: A Challenging Concept. Published online on 09 Mar 2015.

37. Oikonomou, I., Brooks, C., \& Pavelin, S. (2012). The impact of corporate social performance on financial risk and utility: a longitudinal analysis. Financial Management, 41, 483-515.

38. Orlitzky, M., Schmidt, F. L., \& Rynes, S. L. (2003). Corporate social and financial performance: a meta-analysis. Organization Studies, 24(3), 403-441.

39. Pearce, C. L., \& Manz, C. C. (2011). Leadership Centrality and Corporate Social IrResponsibility (CSIR): The Potential Ameliorating Effects of Self and Shared Leadership on CISR. Journal of Business Ethics, 102, 563-579. http://dx.doi. org/10.1007/s10551-011-0828-7

40. Popa, M., \& Salanță, I. (2014). Corporate social responsibility versus corporate social irresponsibility. Management \& Marketing: Challenges for the Knowledge Society, 9(2), 137-146.

41. Romani, S., Grappi, S., \& Bagozzi, R. P. (2013). My anger is your gain, my contempt your loss: Explaining consumer responses to corporate wrongdoing. Psychology \& Marketing, 30(12), 1029-1042.

42. Roubini, N., \& Mihm, S. (2010). Crisis economics: A crash course in the future of finance. London: Allen Lane.

43. Singer, M. S. (2000). Ethical and Fair Work Behaviour: A Normative-Empirical Dialogue Concerning Ethics and Justice. Journal of Business Ethics, 28, 187-209.

44. Stokes, P. (2015). The Janus Dialectic of Corporate Social Irresponsibility and Corporate Social Responsibility - The 
Role of Micro-Moments. In Corporate Social Irresponsibility:

A Challenging Concept. Published online 09 Mar 2015, 83-108. http://dx.doi.org/10.1108/S20439059(2012)0000004013

45. Strike, V., Gao, J., \& Bansal, P. (2006). Being good while being bad: social responsibility and the international diversification of US firms, Journal of International Business Studies, 37, 850-862.

46. Tang, Y., Qian, C., Chen, G., \& Shen, R. (2015). How CEO hubris affects corporate social (ir) responsibility. Strategic Management Journal, 36(9), 1338 1357.

47. Tench, R., Sun, W., \& Jones, B. (2015). The Challenging Concept of Corporate Social Irresponsibility: An Introduction. In Corporate Social Irresponsibility: A Challenging Concept. Published online 09 Mar 2015, 3-20. http:// dx.doi.org/10.1108/S20439059(2012)0000004009

48. Tett, G. (2010). Fool's gold: How unrestrained greed corrupted a dream, shattered global markets and unleashed a catastrophe.

London: Abacus.

49. Thomas, J. B., Clark, S. M., \& Gioia, D. A. (1993). Strategic sense making and organizational performance: Linkages among scanning, interpretation, action, and outcomes. Academy of Management Journal, 36(2), 239270

50. Treanor, J. (2012). Barclays just the tip of the iceberg as banking braced for more scandals. The Observer, 8 July.

51. Trevino, L. K., \& Brown, M. E. (2004). Managing to Be Ethical: Debunking Five Business Ethics Myths. Academy of Management Executive, 18(2), 69-80.

52. Vogel, D. (1992). The globalization of business ethics: Why America remains distinctive. California Management Review, 35(1), 30-49.

53. Wagner, T., Bicen, P., \& Hall, Z. R. (2008). The dark side of retailing: Towards a scale of corporate social irresponsibility. International Journal of Retail and Distribution Management, 36(2), 124-142.
54. Walker, K., \& Wan, F. (2012).

The harm of symbolic actions and green-washing: corporate actions and communications on environmental performance and their financial implications. Journal of Business Ethics, 109(2), 227-242.

55. Walker, K., Zhang, Z., \& Yu, B. (2016). The angel-halo effect: How increases in corporate social responsibility and irresponsibility relate to firm performance. European Business Review, 28(6), 709-722. http://dx.doi.org/10.1108/ EBR-11-2015-0139

56. Weaver, G. R., Treviño, L. K., \& Agle, B. (2005). Somebody I look up to: Ethical role models in organizations. Organizational Dynamics, 34(4), 313-330.

57. Windsor, D. (2013). Corporate social responsibility and irresponsibility: A positive theory approach, Journal of Business Research, 66, 1937-1944.

58. Zahra, S. A., Priem, R. L., \& Rasheed, A. A. (2005). The antecedents and consequences of top management fraud. Journal of Management, 31(6), 803-828. 